\title{
As Jurisdições Supranacionais em Matéria Penal
}

\author{
Sandro Brescouit Trotta
}

1 Introduçấo. 2 Tribunal de Nurembergue. 3 Tribunal de Tóquio - Tribunal Militar Internacional do Extremo Oriente. 4 Tribunal Penal Intemacional para a Ex-lugoslávia. 5 Tribunal Penal Internacional para Ruanda. 6 Consideraçóes acerca dos Tribunais "Ad Hoc". Quadro 1 Comparativo dos Tribunais "Ad Hoc". 7 Tribunal Penal Internacional (Tpi). Quadro 2 - Tribunal Penal Internacional (Tpi). 8 Conclusão. Referências.

Resumo: O presente estudo se propóe a analisar a evoluçáo do exercício jurisdicional supranacional, em matéria penal, ou seja, as hipoteses de conduta delitiva con efeitos para além das fronteiras territoriais, e dos limites de competência do Estado soberano, quando a soluçăa pacifica dos conflitos năo se mostra suficiente, com ênfase nas contendas ocorridas entre naçōes, nos casos de genocídio, crimes contra a Humanidade, de guerra, agressăo, ou, ainda, aqueles crimes cometidos por líderes políticos de Estados soberanos em detrimento de outros Estados, ou de particulares, ou, ainda, aqueles cometidos por particulares, mas cujos efeitos causam danos a inúmeras pessoas situadas em um ou mais terntónios. Arrolados os principais tipos penais em espécie, parte-se de uma breve abordagem histórica, dos chamados tribunais "ad hoc", até o principal organismo de natureza supranacional, em matéria penal hoje existente, que é o Tribunal Penal Internacional (TPI), buscando-se demonstrar a evolução do exercício jurisdicional supranacional em matéria penal.

Palavras-chave Jurisdiçäo. Penal Supranacional. TP1. Tribunais "ad hoc".

Abstract: This study aims to examine the evolution of the exercise supranational court in criminal matters, namely the chances of criminal conduct with effect beyond the teritorial boundaries and the limits of jurisdiction of a sovereign state, when the peaceful settlement of conflicts not appears sufficient, with emphasis on disputes arising between nations, in cases of genocide, crimes against humanity, war, aggression, or even those crimes committed by political leaders of sovereign states at the expense of other states, or individuals, even those committed by individuals, but whose effects causing damage to many people located in one or more territonies. Listed the main criminal in kind, is part of a brief historical approach, called the court "ad hoc", until the

\footnotetext{
Especialista em Dir. Internacional Público, Privado e da Integraça (UFRGS), Mestre em Ciênciäs Criminais (PUC) e Doutorando em Altos Fstudos Contemporâneos (Universidade de Coímbra/Portugal).
} 
main body of supranational nature, in criminal matters, we see today, which is the International Criminal Court (ICC), seeking to demonstrate the evolution of the exercise supranational court in criminal matters.

Keywords: Jurisdiction Criminal Supranational. ICC. Courts ad hoc.

\section{Introdução}

Embora vivamos na efervescência do mundo globalizado, com toda uma série de alteração de paradigmas (entre os quais, brevemente, cabe destacar, a questão da reformulação dos conceitos de fronteiras, a velocidade de comunicação, informação e deslocamento, bem como a "diminuição" das distâncias territoriais), o fató é que até a bem pouco tempo atrás, as nações buscavam assegurar seu poderio mediante a conquista de territórios geográficos que thes assegurassem respeito e autonomia, principalmente por meio do exercício bélico.

Com a evoluçăo dos meios de comunicação, hoje sabemos, em tempo real, fatos acontecidos em qualquer lugar do mundo. Nessa evoluçâo da humanidade, todos os campos da ciência sofrem alteraçōes. No âmbito jurídico, não poderia ser diferente.

Esse estudo propōe-se a analisar o processo evolutivo da humanidade, em seu aspecto jurídico, nos (vários) momentos em que a soluçăo pacífica dos conflitos năo foi suficiente, causando efeitos, no campo da ciência jurídica, classificados como de direito internacional penal.

Tal hipótese tem razão de ser ao considerarmos que, se no âmbito do exercício jurisdicional interno, as questōes já săo de dificilima soluçáo fática, como proceder, quando nos deparamos com conflitos específicos ocorridos entre naçóes, como nos casos de genocídio, crimes contra a Humanidade ou de guerra?

É reconhecido que contamos, atualmiente, com uma estrutura estatal absolutamente ultrapassada e paradoxal, segundo a 
qual, nos dizeres de Flávia Piovesan, ${ }^{2}$ "quem mata uma pessoa tem mais chance de ser julgado do que quem mata 100 mil pessoas", no que se poderia traduzir em uma "desagradável sensação de esquizofrenia produzida pelo conflito entre discurso e realidade da pena criminal". ${ }^{3}$

De fato, sejam crimes cometidos por líderes políicos de Estados soberanos em detrimento de outros Estados, ou de particulares, ou, ainda, aqueles cometidos por particulares, mas cujos efeitos causam danos a inúmeras pessoas, o fato é que a repressão ou tentativa de controle dos delitos que nấo foram julgados no âmbito interno, ou cujas consequências ultrapassam os (cada dias mais flexiveis) limites da soberania, o fato é que tais condutas näo podem restar sem julgamento por mera ausência de disposição legal (em nível mundial) ou pelo receio de ferir a autonomia de outro país (ainda que isso sirva comumente como ferramenta à impunidade dos agentes com poderes políticos e financeiros para fazê-lo).

Tendo como referencial o campo da ciência penal, deve se atentar que "As injustiças cometidas podem ser de tão diferente gravidade e qualidade que a formulação de directrizes válidas em geral parece, todavia, problemática. $\mathrm{O}$ número e a qualidade das injustiças são, por isso, indicadores importantes para julgar o valor do direito, em especial do Direito Penal, na compreensāo das injustiças dos sistemas totalitários." 4

\footnotetext{
${ }^{2}$ PIOVESAN, Flavia. Título. Disponivel em:

$<$ http//wwwdhnetorgbr/direitos/militantes/flaviapiowesan/piovesan_ruanda html $>$ Acesso em: 03 mar. 2005.

3 SANTOS Juarez Cirino dos. Novas hipóteses de criminalização. In: CONFERÊNCIA NACIONAL DOS ADVOGADOS. CIDADANIA, ETICA E ESTADO, 18., 2002, Salvador Anais... Brasilia: OAB, Conselho Federal, 2003. v.1. p. 938.

4 O Direito Penal como reaçáo às injustiças do sistema - visäo comparativa da política de tratamento do passado do ponto de vista penal depois da mudança de sistema. Um relatónio de investigaçăo do Instituto Max-Planck para Direito Penal Estrangeiro e internacional, Freburg i. Br. Albin Eser e Jörg Arnold, na obra Direito Penal Internacional para a Proteção dos Direitos Humanos. Simpósio da Faculdade de Direito da Universidade de Coimbra e Goethe-Institut de lisboa, Fim de Século, 2003, p. 24.
} 
O tema objeto de análise diz respeito ao exame dos delitos de natureza penal internacional e sua repressão.

Arrolados os principais tipos penais em espécie, o estudo parte de uma breve abordagem histórica, dos chamados tribunais "ad hoc", até o principal organismo de natureza supranacional, em matéria penal, hoje existente, que é o Tríbunal Penal Internacional, buscando-se demonstrar a evolução jurisdicional ocorrida.

Não se procurou, aqui, asseverar qual foi o efetivo primeiro Tribunal a ter atuação supranacional, mas, uma das primeiras notícias que se tem, ocorreu em 1474, quando houve, na Alemanha, o julgamento de Peter von Hagenbach, condenado e executado por decisão de 27 juízes provenientes da Alemanha, Suíça, Alsácia e da Áustria, sob a acusação de haver determinado às suas tropas que estuprassem, matassem civis inocentes e pilhassem propriedades, num período em que năo havia hostilidades, violando leis Divinas e Humanas). ${ }^{5}$ Posteriormente, houve a menção de que a "idéia de criação de um Tribunal Penal Internacional remonta do ano de 1872, quando Gustavo Moynier apresentou em uma Conferência da Cruz Vermelha, a primeira proposta formal direcionada ao estabelecimento de tal Tribunal ${ }^{6} ;{ }^{6}$ no entanto, para fins acadêmicos, entende-se que a primeira previsão legal concernente à criação de um Tribunal Penal Internacional se deu em 28 de junho de 1919, com o Tratado de Paz de Versalhes, em 28 de junho de 1919.?

E a utilização de tal via "judiciária" (e a referência tem razão de ser, pois muito se questionou na época, a respeito de sua legitimidade, tanto que um termo análogo era "Tribunais Militares") se deu logo após a $2^{a}$ Grande Guerra. No transcurso dessa, foram vistas as maiores atrocidades do mundo

\footnotetext{
5 JAPIASSÚ, Carlos Eduardo Adriano: O Tribunal Penal Internacional a intemacionalização do direito penal. Rio de Janeiro: Lúmen Júris, 2004. p. 37.

- SIVA, Pablo Rodrigo Alflen da. Tribunal Penal Internacional: aspectos fundamentais e o novo Código Penal Internacional alemäo. Porto Alegre: Fabris, 2004. p. 17.

${ }^{7}$ SILVA, F, 2004, p. 18.
}

Cadernos do PPG em Direito UFRGS, Porto Alegre, v. 6, n. 7 e 8, p. 489-512, 2007. 
moderno. Vencidas as nações agressoras, julgou-se neces sária a instalação de Tribunais destinados a apurar e punir os graves atentados cometidos contra os mais basilares direitos humanos: Criam-se, então, os Tribunais de Nurembergue e Tóquio (também denominado "Tribunal do Extremo Oriente").

\section{Tribunal de Nurembergue}

Por meio de um Convênio Internacional que teve como celebrantes os EUA, o governo provisório da França, $\mathrm{O}$ Reino Unido e a URSS, foi firmada em Londres, em 08 de agosto de 1945, e aberto à adesão de todas as naçốes, a deliberaçäo de formar o que viria a se denominar Tribunal de Nurembergue (na chamada Carta de Londres). Além de que o referido documento "preenchia" o fundamento legal para $\mathrm{o}$ indiciamento dos acusados, sua localização geográfica colaborava para o efetivo exercício jurisdicional.

Na realidade, sua criação foi motivada muito mais por conotações políticas que jurídicas, com o escopo de julgar criminosos do regime nazista (e atos ordenados por Hitler contra o povo judeu). Além de membros do governo terem sido julgados (24 membros do partido e do governo nazista), também foram apreciadas as condutas de outras 08 (oito) organizaçốes dentre as quais se destacava a classe médica (sendo diversos de seus integrantes considerados criminosos de guerra por conta das experiências realizadas com humanos e as decisóes sobre pessoas que deveriam ser eliminadas).

No artigo $6^{\circ}$ da chamada Carta de Londres, havia a previsão dos "crimes contra a paz, de agressão, guerra" e (enfim) "contra a humanidade" ("já se afirmou que a maior virtude do Tribunal de Nurembergue foi ter incorporado ao debate jurídico e político a noção de crime contra a humanidade"). ${ }^{8}$ Tal Corte mesclou os direitos civis europeus e anglo-americanos

\& CANÊDO, Carlos. O genocidio como crime internacional Belo Horizonte: Del Rey, 1999. p. 73 . 
no afã de levar a julgamento os respon-sáveis pela morte de milhares de pessoas.

Ao longo do funcionamento do Tribunal de Nurembergue, entre 1945 e 1946, a grande crítica que contra ele se levantou, foi a de haver aplicado a "justiça do vencedor" (aí incluídos os EUA, o Reino Unido, a União Soviética e a França, que, como já manifestado, criaram a Carta do Tribunal Internacional Militar) pois, "como os Aliados estavam exercendo poder soberano sobre os territórios alemaes ocupados, pode-se dizer que os processos eram praticamente de natureza doméstica", além de que, entre outras características já sucintamente observadas, não houve "estrita observância ao princípio da reserva legal, dogma indispensável em um Direito Penal de índole democrática", ${ }^{10}$ tendo sido permitido "ao tribunal declarar que uma organização tenha essência criminosa", que "o processo pode ser feito contra um acusado, mesmo na sua ausência", "que o Tribunal nằo está vinculado às regras técnicas de administração da prova e deve admitir qualquer elemento que pareça ter um valor de prova, além de não haver previsão de recurso"."1

Entendemos que a mais embasada crítica ao referido Tribunal, na doutrina nacional, foi a lecionada por Nelson Hungria: ${ }^{2}$

O Tribunal de Nurembergue há de ficar como uma nódoa da civilização contemporânea: fez tábula rasa do 'nullum crimen nulla poena sine lege' (com um improvisado Plano de julgamento, de efeito retroativo, incriminou fatos pretéritos e impôs aos seus autores o 'enforcamento' e penas puramente arbitrárias); desatendeu ao princípio da 'territorialidade da lei penal'; "estabeleceu a responsabilidade

\footnotetext{
${ }^{9}$ MAIA Marrielle Tribunal Penal Internacional aspectos institucionais, furisdiçâo e princípio da complementaridade. Belo Horizonte: Del Rey, 2001. p. 49

10 CANEDO, 1999, p. 21.

BAZELAIRE, Jean-Paul, CRETIN, Thierry. A justiça penal intemacional. Săo Paulo: Manole, 2003, p. 22-23.

12 HUNGRIA, Nelson. Comentários ao Código Penal. 4. ed. Rio de Janeiro: Forense, 1958.v.1, t. 1. p. 31.
} 
penal de indivíduos participantes de tais ou quais associações, ainda que alheios aos fatos a eles imputados, funcionou em nome dos vencedores, que haviam praticado os mesmíssimos fatos atribuídos aos réus; suas sentenças eram inapeláveis, ainda quando decretavam a pena de morte.

Dentre especiais particularidades, há de se registrar os três elementos definidores da Jurisdiçáo do Tribunal de Nurembergue: ${ }^{13}$

a) Um elemento real-objectivo: só caiam sob a jurisdição do tribunal os fatos descritos no art. $6^{\circ}$ da Carta de Londres (agressấo, genocídio etc.); este era o elemento que dava sentido à existência de uma jurisdição intemacional, por se tratar de crimes contra o direito internacional.

b) Um elemento pessoal-subjetivo: a jurisdição do tribunal restringia-se aos fatos praticados no interesse de um País do Eixo-Europeu; este elemento permitia excluir liminarmente a análise da responsabilidade das forças aliadas, por fatos eventualmente análogos aos que se encontravam em julgamento, nas chacinas de Hiroshima e Nagasaqui, na razia de Dresden, no massacre da floresta de Katyn, etc.

c) E, enfim, um elemento implícito de reserva de jurisdição sobre os 'majors war criminals' (jurisdição especial), que permitia evitar que uma das potências pudesse julgar sozinha os principais responsáveis do Eixo e colher os inerentes louros perante a comunidade intemacional.

Outra crítica que merece observação diz respeito à ausência de tipos penais fechados, o que significou um campo fértil para a violação (especialmente) do princípio da legalidade. É importante reconhecer que esta foi uma das primeiras experiências de integração de dois diferentes ramos

\footnotetext{
13 CAERO, Pedro. Tribunais Penais linternacionais: etapas de um carninho ou astros em constelação, doutrina intemacional. Revista Brasileira de Ciências Criminais, Săo Paulo, n. 37. 2002, p. 103
} 
do direito em uma situação concreta, a saber, os direitos penal e internacional.

A mescla desses importantes institutos fez-se materializada com o atual Estatuto de Roma, mas a presente apreciação diz respeito a um projeto, na época, absolutamente inédito. Por isso a crítica à ausência de tipos penais fechados deve ser valorada năo só pela qualidade do ineditismo, como também pelo fato de que as principais normas de direito internacional (em total contrariedade ao direito penal) são efetivamente tipos penais abertos, pois, em se tratando dos interesses de mais de um Estado, por certo que se faz necessária a flexibilidade.

Ainda que sucintamente levantadas as principais críticas ao primeiro Tribunal ad hoc, constituído com o objetivo de julgar os crimes contra a paz, de agressão, de guerra e contra a humanidade, não se pode olvidar que seu intuito foi razoavelmente atingido. Além de buscar coibir novos crimes dessa natureza, não só fez projeção de penalidades como as aplicou, pela primeira vez, em desfavor de sujeitos individuais, não mais se repetindo a tradição de punir os Estados. $\mathrm{Na}$ mesma linha, repudiou-se a principal tese defensiva, nos casos de cometimento dos delitos antes referidos, na qual se "justificava" a autoria e a materialidade delitivas em nome de obediência às normas proferidas por oficiais superiores.

Por outro lado, sempre com a óptica parcimoniosa necessária em questões desse gênero, e sem nunca esquecer a necessidade do oferecimento de garantias ao réu (independentemente da gravidade do delito), é importante perceber que a instituição da referida Corte de Nurembergue buscou não meramente oferecer revanchismo às inúmeras mortes protagonizadas pelo governo alemão, cuja maneira mais comum seria com mais invasóes e derramamento de sangue, por parte dos aliados, em uma punição a um Estado inteiro (ou a membros de uma organização), mas sim a opção de um julgamento sendo apreciadas provas, prática da jurisdiçăo por juízes de carreira etc. Para tanto, diante das falhas 
apresentadas (comum a um projeto neófito e de especial relevância como o ocorrido em Nurembergue), operou-se o exercício da jurisdição para reprimir crimes graves, de repercussão mundial, e isto deve ser visto como algo bastante louvável.

Como resultado do exercício jurisdicional (neste quadro: de 04 juízes, do Reino Unido, USA, França e da URSS), 3 (três) pessoas foram absolvidas, houve 12 condenações à morte, 3 prisões perpétuas, 2 condenações de 20 anos de reclusão, uma de 15 anos e outra de 10 anos de reclusão.

Entendemos que o pensamento vigente, na época, foi bem traduzido na primeira audiência do processo de Nurembergue:14 "O privilégio de abrir o primeiró processo na história dos crimes contra a paz do mundo é uma grande responsabilidade. As quatro grandes nações vitoriosas [...] detêm o braço da vingança e submetem voluntariamente os seus inimigos prisioneiros ao julgamento da lei. Os crimes pelos quais buscamos condenar e punir foram a tal ponto premeditados, perversos e devastadores que a civilização não pode tolerar que sejam ignorados, pois não poderíamos sobreviver se eles fossem reiterados."

\section{Tribunal de Tóquio - Tribunal Militar Internacional do Extremo Oriente}

O Estatuto do Tribunal Militar Internacional do Extremo Oriente; lançado em $1^{\circ}$ de dezembro de 1943 , na conferência do Cairo, teve como subscritores representantes chineses, britânicos e americanos. Na ocasião, foi declarada a intenção de pôr termo à agressão japonesa, com o julgamento dos criminosos de guerra. Assim, em 19 de janeiro de 1946, quando já em curso os trabalhos em Nurembergue, foi instituído o referido Tribunal Militar Internacional para o Extremo Oriente, composto de 11 magistrados, cujo objetivo era o de levar

14 BAZELAIRE; CRETIN, 2003, p. 42. 
a julgamento as autoridades japonesas pelos conflitos ocorridos entre 1937 a 1941, cuja maior repercussão foi o "famoso bombardeio a Pearl Harbour ${ }^{\mathrm{n}} 5$.

Embora idealizado nos termos de Nurembergue, foram concedidos "aos acusados os direitos mais fundamentais de notificação em tempo útil do ato de acusação, de assistência por um advogado, da possibilidade de fazer ouvir testemunhas de defesa e de contra-interrogar as testemunhas de acusaçắo e de acompanhar todas as fases do processo em seu idioma." ${ }^{16}$ Também aqui não houve previsão recursal, nem pôde ser utilizado como argumento defensivo de exoneração de responsabilidade a obediência a ordens recebidas de governante ou superior, sendo estabelecido o princípio de responsabilidade dos dirigentes pelos atos previstos como crime.

As atividades do Tribunal desdobraram-se de 29 de abril de 1946 a 12 de novembro de 1948 e a competência previa o julgamento de crimes contra a paz, crimes contra as convenções da guerra e crimes contra a humanidade. Foram acusadas 28 pessoas, sendo 9 civis e 19 militares de carreira.

Uma particularidade que importa revelar, e que define bem a falibilidade do sistema de julgamento criado, foi o fato de que cada réu teve em sua defesa, um advogado japonês e outro norte-americano (sendo os EUA um dos países acusadores, financiadores do Tribunal, que havia imposto a rendição ao governo japonês e seu Comandante Supremo podia escolher os juízes e reduzir as penas, só não podia aumentálas).

Assim como em Nurembergue, também no Tribunal Militar para o Extremo Oriente, os Aliados cuidaram de executar, na opinião de inúmeros doutrinadores, uma jurisdição "de vencedores". Chama a atenção que o imperador Hiroito, o primeiro dos criminosos de guerra, não tenha sido julgado,

\footnotetext{
"SANEDDO, 1999, p. 79.

is BAZELAIRE, CRETIN, op. cit, p. 29.
} 
bem como o fato de vários criminosos (de guerra) japoneses terem sido libertados pelos norte-americanos, sem qualquer processo tal como os médicos da "unidade 731" (responsáveis por experimentos humanos). ${ }^{17}$

\section{Tribunal Penal Internacional para a Ex-Iugoslávia}

Ainda que seja missáo bastante difícil precisar uma ordem cronológica para a confusa guerra da ex-República Socialista Federal da lugoslávia, para fins do presente estudo, pode-se estabelecer como termo inicial a data de 25 de junho de 1991, quando a República da Eslovênia proclamou-se independente da lugoslávia. A segunda fase do conflito foi relativo à Croácia; o terceiro momento deu-se na Bósnia e Herzegovina, sobrevindo, por fim, o período de Kosovo.

Gravíssimos crimes contra os Direitos Humanos se fizeram presentes após tais acontecimentos bélicos, sendo comuns as violações não só no campo do Direito Internacional Humạnitário, como também do Direito Internacional Penal, com a reiterada prática de genocídio e demais crimes, aos quais se convencionou chamar de depuração étnica (entre as espécies de delitos que configuraram tal denominação, foi noticiado o cometimento de homicídios, torturas, encarceramentos arbitrários, execuçóes sem processo judicial, estupros e outras agressões sexuaís em praça pública e envolvendo desde crianças de 7 anos a idosos, confinamento de populaçōes civis em guetos, expulsões pela força, deslocamento e deportação de civis, destruição injustificada de bens, entre outros).

Por intermédio da Resolução 827 , de 25 de maio de 1993, foi criado o Tribunal Internacional com o único fim de julgar as pessoas presumidamente responsáveis pelas graves violaçốes ao Direito Intemacional Humanitário cometidas no território da ex-lugoslávia entre o dia $1^{\circ}$ de janeiro de 1991 e a data em que se celebrar a paz. Pela mesma Resolução, foi aprovado o Estatuto do Tribunal.

${ }^{17}$ BAZELAIRE: CRETIN, 2003, p. 37. 
O Tribunal Penal Internacional para a ex-Iugoslávia, ${ }^{18}$ também conhecido como TIPIAJ, com sede na Haia (Países Baixos), tem competência para processar e julgar violaçôes graves às Convenções de Genebra, de 1949, violaçốes às leis e aos costumes da guerra, genocídio e crimes contra a humanidade, que tenham sido cometidos no território da antiga Iugoslávia, a partir de 1991.

Importante registrar a especial particularidade de que tal Tribunal foi instituído quando os conflitos ainda estavam em curso, sendo um desses, seus pressupostos cumulativos, como segue: 19

a) Um elemento real-objetivo: o tribunal só tem jurisdição sobre os crimes incluídos no catálogo dos arts. $2^{\circ}$ e seguintes do Estatuto;

b) Um elemento temporal: só caem sob a jurisdição do tribunal os fatos praticados a partir de 01.01.91;

c) Um elemento territorial: o tribunal só tem jurisđição sobre os fatos cometidos no território da antiga lugoslávia;

d) A quarta nota importante da jurisdição do TIPIAJ é o princípio da primazia. Dada a desconfiança política em relação à justiça administrada pelos tribunais estaduais naquele território, o princípio da primazia confere ao TIPIAJ o direito de avocar um caso que esteja a ser por eles processado e, além disso, manda que se mantenha a jurisdiçao do tribunal intemacional se os tribunais estaduais tiverem qualificado o crime como comum ou se houver suspeita de fraude judíciária.

Sua composiçăo é de 16 (dezesseis) juízes permanentes (eleitos pela Assembléia Geral da ONU, por um mandato de 4 anos, com direito à reeleiçăo) $\mathrm{e}$, no máximo, nove juízes ad

\footnotetext{
12 As informaçós aqui constantes podem ser encontradas no site oficial do Tribunal (www org/icty).

19 CAIERO, 2002, p. 103
} 
litem, escolhidos pela Assembléia Geral, sem direito à reeleição, por período não superior a 3 anos.

Outra particular novidade em relação a Tóquio e Nurembergue é que a composição prevê três Câmaras de Julgamento e uma Câmara de Apelação (nos casos anteriores não havia possibilidade de recurso).

Também o particulariza o fato de não existír julgamento in absentia, pois é necessáría a presença física do acusado perante o Tribunal, havendo uma Seção de Vítimas e de Testemunhas (o que visa a garantir segurança aos acusados).

Durante a tramitação do processo, os acusados são mantidos presos na Unidade de Detenção do TIPIAJ, (no bairro penitenciário) em Haia. Entre as penalidades, a maior é a de prisão perpétua, podendo as penas ser cumpridas em qualquer Estado que tenha assinado compromisso com a ONU de receber pessoas condenadas pelo TIPIAJ.

Dados apontam ${ }^{20}$ a existência de 77 (setenta e sete) indiciados, sendo que 56 (cinqüenta e seis) respondem a processo perante o Tribunal. Desses, 47 (quarenta e sete) estão detidos, 9 (nove) provisoriamente soltos e 21 (vinte e um) foragidos.

Desde a criaçăo do TIPIAJ, contudo, foram mais de 90 (noventa) os indiciados, sendo que, destes, 4 (quatro) já faleceram, 7 (sete) cumprem pena, 3 (três) já cumpriram pena, 9 (nove) foram absolvidos ou tiveram seu indiciamento negado.

As principais críticas são no sentido de que:

a) O Tribunal fora estabelecido ilegalmente, pois foi criado pelo Conselho da ONU e não por um tratado internacional;

b) Não havia justificativa para a previsão de primazia do Tribunal sobre cortes nacionais competentes;

20 JAPIASSÚ, 2004, p. 100. 
c) Não havia competência do Tribunal para julgar o caso, visto que os crimes relacionados referiam-se a conflitos amnados internacionais e o caso iugoslavo relacionava-se com conflito armado interno.

Permanece aguardando o tramitar processual e julgamentos Milan Milutinovic (Presidente da República da Sérvia). Slobodan Milosevic (então Presidente da República Federal da lugoslávia e comandante supremo das forças armadas), um dos mais importantes homens de Estado envolvidos naquele conflito, que também estava preso, aguardando julgamento, faleceu em fevereiro de 2006.

\section{Tribunal Penal Internacional para Ruanda}

Antes do exame da Corte penal instaurada em Ruanda, é importante uma pequena descrição dos fatos que acarretaram os horrendos conflitos lá vislumbrados.

Trata-se de um país localizado no leste do continente africano, que teve sua independência consolidada em 1962. Sua população é composta basicamente por duas etnias principais, quais sejam, os hutus (que representam cerca de 4 5 da populaçăo local), e os tutsis. A desigualdade numérica também tem raízes históricas, considerando que os primeiros lá chegaram entre 500 a.c. e o final do primeiro milênio. Os tutsis, por seu turno, provenientes do nordeste da África, entre os anos 1400 e 1700 .

$O$ conflito entre as etnias teve um significativo aumento em 1994, quando houve graves problemas políticos que se intensificaram após o atentado contra o Presidente de Ruanda, Juvénal Habyarimana, quando seu avião, no qual também estava o presidente de Burundi, Cyprien Ntaryamira, foi abatido em Kigali (capital do país), em circunstâncias e autoria não esclarecidas ou identificadas.

Diante de tais fatos, a guarda presidencial e os militares extremistas hutus instalaram barricadas na capital e começaram um conflito que acarretou a morte de mais de 500.000 pessoas. 
Dentre as atrocidades, tornadas "comuns" em tempos de guerra, no dia seguinte ao início do conflito, nada foi poupado da violência: nem mesmo hospitais ou igrejas, no que se denominou verdadeiro "acesso de ódio tribal entre as etnias hutus e tutsis." 21

Em 30 de junho, a Comissão de Direitos Humanos da ONU publicou um relatório que enfatizava o caráter sistemático do genocídio. Por intermédio da Resolução 955, de 8 de novembro de 1994 , criou o Tribunal Penal Intemacional (também ad hoc) para Ruanda (TPIR).

Sua competência fica atrelada ao julgamento das pessoas presumidamente responsáveis por atos de genocídio e outras violações graves ao Direito Internacional Humanitário, cometidos não só no território de Ruanda, mas também envolvendo cidadãos ruandenses, que tenham desenvolvido atividades criminosas entre $1^{\circ}$ de janeiro e 31 de dezembro de 1994. Há de salientar-se que os conflitos ocorreram na seara doméstica (ou seja, um conflito armado näo-internacional ${ }^{22}$ ); no particular, também é impositivo registrar que a competência jurisdicional incluía os fatos ocorridos "nos territórios dos países limítrofes, durante aquele período por cidadâos ruandeses." "23 Ou seja, há a particularidade de apreciação de casos em que há conflito armado não-intemacional.

Sua constituição teve como esteio as linhas previstas no Tribunal Penal Internacional para a ex-Iugoslávia, tendo como principal diferença que, em seu art. $5^{\circ}$, os crimes contra a humanidade sâo considerados como "aquelas condutas cometidas como parte de um ataque sistemático ou comum contra qualquer populaçáo civil por motivo nacional, político, étnico, racial ou religioso." "24.

As áreas de competência material do TPIR são, outrossim, o genocídio (art. $2^{\circ}$ do Estatuto), crimes contra a humanidade

\footnotetext{
2. BAZELAIRE, CRETIN, 2003, p. 57

MAIA, 2001, p. 45.

CALERO, 2002, p. 104

24. SILVA, P., 2004, p. 28
} 
(art. $3^{\circ}$ ) e as violações do art. $3^{\circ}$ comuns às convenções de Genebra de 1949 e ao protocolo adicional (art. $4^{\circ}$ ), sendo, nos demais aspectos, bastante similar ao Tribunal constituído em Haia, para apurar os fatos ocorridos na ex-lugoslávia.

A contar do primeiro indiciamento, em 28 de novembro de 1995, outros 70 (setenta) já ocorreram, havendo cerca de 60 (sessenta) prisões sendo cumpridas em Arusha. Também já se deu o julgamento de 09 (nove) acusados, com 08 (oito) condenaçôes e uma absolvição. A Câmara de Apelação confirmou seis sentenças, dois aguardam julgamento dos recursos e oito, de um total de 21 acusados, ainda esperam pela decisáo originária.

Pela primeira vez desde a $2^{\mathrm{a}}$ Grande Guerra, em setembro e outubro de 1998, um Tribunal Penal Intemacional efetua condenações pelo crime de genocídio.

Como última particularidade específica do referido Tribunal "ad hoc", há de se ressaltar "que a violência sexual é considerada genocídio quando cometida com a intenção de eliminar um grupo de pessoas da mesma raça ou origem." 25

\section{Considerações acerca dos Tribunais "AD HOC"}

Os casos dos Tribunais de Ruanda e da ex-Iugoslávia distanciam-se dos Tribunais de Nurembergue e Tóquio, pois foram instituídos pela comunidade internacional e não impostos pelos vencedores aos vencidos.

O que se buscou demonstrar é a evoluçấo ocorrida no direito penal que ultrapassa as fronteiras ou, ainda, que regula, no caso, os crimes de repercussão internacional.

A análise histórica ainda que breve, permite que se vislumbre claramente o avanço nâo só de medidas adotadas com o condão de pôr fim às atrocidades comuns em guerras, genocídios, ou a morte de multidóes, no que denominamos crimes contra a humanidade, como também oferece condições de

${ }^{25}$ BAZELAIRE; CRETIN, 2003, p. 60. 
avaliar o crescimento de um ramo que, não obstante ser novo, passará a ser cotidiano em nosso enfrentamento daqui por diante, que é o direito penal internacional. À seara do direito internacional, aliás, muitos outros ramos do direito buscarão criar alianças, porquanto esta é a realidade com que convivemos hoje e não há porque pensarmos em sentido diverso que, no caso, seria um retrocesso do processo globalizatório.

A evolução que se pretendeu demonstrar está longe de ter alcançado sua maioridade. Como salientado, muitas foram as críticas atinentes aos tribunais "ad hoc" (literalmente, criados "para isso"), mas foi graças a eles que se permitiram experiências suficientes que pudessem desencadear a realização de um antigo sonho: a criação de um tribunal permanente com competência para julgar crimes cuja abrangência atinja mais de uma nação, no que se poderia chamar de jurisdição penal universal. 


\begin{tabular}{|c|c|c|c|c|}
\hline $\begin{array}{l}\text { TRIBUNAIS } \\
\text { Ad HOC }\end{array}$ & $\begin{array}{l}\text { TRIBUNAL DE } \\
\text { NUREMBERGUE } \\
(1945-1946)\end{array}$ & $\begin{array}{l}\text { TRIBUNAL MILTTAR } \\
\text { INTERNACIONAL DO } \\
\text { EXTREMO ORTENTE } \\
(1946-1948)\end{array}$ & $\begin{array}{l}\text { TRIBUNAL PENAL } \\
\text { INTERNACIONAL PARA A } \\
\text { EX-IUGOSLAVIA (de O1 de } \\
\text { janeiro de } 1991 \text { até hoje) }\end{array}$ & $\begin{array}{l}\text { TRIBUNAL PENAL } \\
\text { INTERNACIONAL PARA } \\
\text { RUANDA (de } 27 \text { de junho de } \\
1995 \text { até hoje) }\end{array}$ \\
\hline SEDE & $\begin{array}{l}\text { Nurembergue } \\
\text { (Alemranha) }\end{array}$ & Tóqưo (Japão) & Haia (Paises Baixos) & Aruśsha (capital da Tanzânia) \\
\hline COMPOSIÇÃOO & $\begin{array}{l}4 \text { magistrados } \\
\text { (Reino Unido, USA, } \\
\text { Franca e URSS) }\end{array}$ & 11 magistrados & $\begin{array}{c}16 \text { magistrados permanentes } \\
\text { (mandato de } 4 \text { anos admitida a } \\
\text { reeleiço). }\end{array}$ & 14 magistrados \\
\hline COMPETENCIA & $\begin{array}{l}\text { Julgar criminosos do } \\
\text { regime nazista e atos } \\
\text { ordenados por Hiter } \\
\text { contra o povo judeu } \\
\text { qualificados como } \\
\text { "crimes contra a paz, de } \\
\text { agressâ, guerra e contra } \\
\text { a humanidade". }\end{array}$ & $\begin{array}{l}\text { Julgar os criminosos de guerra } \\
\text { japoneses pelos conflitos } \\
\text { ocorridos entre } 1937 \text { e } 1941 \\
\text { qualificados como "crimes } \\
\text { contra a paz; coimes contra as } \\
\text { convençoes da guerra e os } \\
\text { crimes contra a humanidade". }\end{array}$ & $\begin{array}{l}\text { Crimes contra os direitos humanos: } \\
\text { prática de genocídio e de } \\
\text { "depuraço étnica" (honicídios; } \\
\text { torturas, execuscoses sem processo } \\
\text { judicial e delitos sexuais) }\end{array}$ & $\begin{array}{c}\text { Julgamento das pessoas responsáveis } \\
\text { por atos de genocidio e outras } \\
\text { violaçốes graves ao Direito } \\
\text { Internacional Humanitário oometidas } \\
\text { en Ruanda e/ou envolvendo cidadâos } \\
\text { ruandenses }\end{array}$ \\
\hline ABRANGÉNCIA & $\begin{array}{l}\text { Membros do partido e do } \\
\text { governo nazista e de } \\
\text { outras organizacóes } \\
\text { (entre as quais se } \\
\text { destociva a classe } \\
\text { médica, por conta das } \\
\text { experiências com } \\
\text { humanos e pelas } \\
\text { decisóes sobre quem. } \\
\text { deveria ser eliminado). }\end{array}$ & $\begin{array}{l}\text { Acusadas } 28 \text { pessoas, sendo } 9 \\
\text { civis e } 19 \text { militares de carreira. }\end{array}$ & $\begin{array}{l}\text { Há } 77 \text { indiciados, sendo que } 56 \\
\text { respondern a processo peranteo } \\
\text { Tribunal, } 46 \text { estäo detidos, } 9 \\
\text { provisoriamente soltos e } 21 \\
\text { foragidos. }\end{array}$ & $\begin{array}{l}\text { Houve cerca de } 70 \text { indiciamentos } \\
\text { (basicamiente, de extremistas da etria } \\
\text { "hutus" contra os "tutsis") restando } 60 \\
\text { prisóes a serem realizadas. }\end{array}$ \\
\hline
\end{tabular}




\begin{tabular}{|c|c|c|c|c|}
\hline $\begin{array}{c}\text { EFETTOS DAS } \\
\text { DECISOEOS }\end{array}$ & $\begin{array}{l}3 \text { pessoas foram } \\
\text { absolvidas; } 12 \\
\text { condenaçóes à morte; } 3 \\
\text { penas de prisão } \\
\text { perpétua; } 2 \text { penas de } \\
\text { prisăo de } 20 \text { anos de } \\
\text { reclusăo; una } \\
\text { condenaça de } 15 \text { anos e } \\
\text { outra de } 10 \text { anos de } \\
\text { reclusão. }\end{array}$ & $\begin{array}{l}\text { Ninguém foi absolvido: } 7 \\
\text { pessoas foram condenadas à } \\
\text { morte; } 16 \text { foram condenados } \\
\text { à prisáo perpétua (destes, } 4 \\
\text { morreram na prisâo - } 12 \\
\text { foram libertados } \\
\text { condicionalmente); houve } \\
\text { uma condenacáto a } 20 \text { anos de } \\
\text { rectusâo e outra de } 7 \text { anos. } \\
\text { Dos demais, } 2 \text { morreram de } \\
\text { causas naturais e } 1 \text { foi } \\
\text { hospitalizado no inicio do } \\
\text { processo e, após, libertado. }\end{array}$ & $\begin{array}{l}3 \text { acusados já cumpritam pena, } 7 \\
\text { ainda a cumprem, } 4 \text { já falecerarm } \\
\text { (incluindo Slobodan Milosevic, ex. } \\
\text { Presidente da República Federal da } \\
\text { Iugoslávia, em fevereiro último) e } 9 \\
\text { foram absolvidos ou tiveram seu } \\
\text { indiciamento negado. }\end{array}$ & $\begin{array}{l}\text { De } 9 \text { acusados jułgados, } 8 \text { receberam } \\
\text { condenacäo, restando umn absolvido. } \\
\text { Há um total de } 21 \text { acusados } \\
\text { aguardando julgamento. }\end{array}$ \\
\hline $\begin{array}{l}\text { PRINCIPAIS } \\
\text { CRIICAS }\end{array}$ & $\begin{array}{l}\text { Juigamentos com } \\
\text { conotaça politica, fol } \\
\text { considerada aplicada "a } \\
\text { justiga do vencedor" pois } \\
\text { os Allados exerciam } \\
\text { poder sobre os territórios } \\
\text { alemäes ocupados. } \\
\text { Franca desobediencia aos } \\
\text { principios da legalidade, } \\
\text { anterioridade e co devido } \\
\text { processo legal. }\end{array}$ & $\begin{array}{l}\text { Fortíssima conotação politica. } \\
\text { que näo levou a julgamento o } \\
\text { Imperador Hiroto } \\
\text { (considerado o primeiro } \\
\text { criminoso de guerra) e os } \\
\text { médicos da "unidacte } 731 \text { " } \\
\text { (responsáveis por experiências } \\
\text { com humanos). } \\
\text { Inexistência de recurso. }\end{array}$ & $\begin{array}{l}\text { "Foi estabelecido pelo Conselho da } \\
\text { ONu e năo por um tratado } \\
\text { internacional; năo haveria } \\
\text { justificativa para a primazia do } \\
\text { Tribunal sobre cartes nacionais } \\
\text { competentes; cuidava-se de conflito } \\
\text { ammado interno (e năo de caráter } \\
\text { internacional). }\end{array}$ & $\begin{array}{l}\text { Estabjelecido peto Conselho de } \\
\text { Segurança da ONU (não por tratado } \\
\text { internacional); tratava-se de questöes } \\
\text { de cardter interno (e nấo de natureza } \\
\text { internacionai). } \\
\end{array}$ \\
\hline $\begin{array}{l}\text { CARÁTER } \\
\text { INOVADOR }\end{array}$ & $\begin{array}{l}\text { Penalizou sujeitos } \\
\text { individuais (näo se } \\
\text { repetindo a tradiço de } \\
\text { punir os Estados); } \\
\text { repudlou a tese defensiva } \\
\text { de obedlëncia hierárquica } \\
\text { e, de forma inédita, } \\
\text { trouxe ao debate juríliço } \\
\text { a expressâo "crimes } \\
\text { contra a humanidade". }\end{array}$ & $\begin{array}{l}\text { Em relacão ao julgamento de } \\
\text { Nurembergue, foram } \\
\text { concedidos aos acusados os } \\
\text { direitos fundamentais de } \\
\text { notificacăo em tempo útili, } \\
\text { assistência de um advogado e. } \\
\text { possibilidade de ouvir } \\
\text { testemunhas, } \\
\text { Descabimento da lese } \\
\text { defensiva de obediência } \\
\text { hierárquica. }\end{array}$ & $\begin{array}{l}\text { O Tribunal fol instituido quando os } \\
\text { conflitas ainda estavam em curso. } \\
\text { Princípio da primazia (diante da. } \\
\text { desconfiança política em relação a } \\
\text { justiç interna). } \\
\text { Há uma Camara de Apelaçăo. } \\
\text { Necessidade da presença fisica do } \\
\text { acusado na audiência. }\end{array}$ & 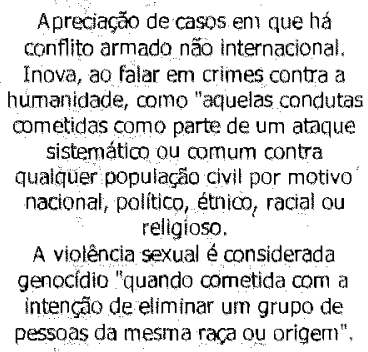 \\
\hline
\end{tabular}




\section{Tribunal Penal Internacional (TPI)}

Em nosso entender, a avaliação decorrente dos resultados oriundos dos Tribunais ad hoc acarretou a necessidade de mudanças na forma de compor os conflitos de natureza universal. A análise, ainda que breve, das principais críticas às cortes de julgamento, criadas com finalidades específicas, levou à elaboração do Estatuto de Roma, e, posteriormente, à criação do Tribunal Penal Internacional.

De qualquer sorte, trata-se de mais um órgã́o, de atuação judiciária, com abrangência além dos limites territoriais. No caso, podem ser protegidos ou figurar como réus aqueles que ratificaram o Estatuto, não sendo fechado, até o momento, o número de assinaturas.

A dificuldade de aceitação de uma instituição desse porte encontra diversas origens. Uma delas, sem dúvida, é o fato de que vivemos num mundo acelerado, cujas fronteiras não se submetem mais a uma designação territorial e/ou mesmo geofísica. No mesmo sentido, é a garantia de que também o Direito precisa se ajustar, devendo ser elaborados novos meios de atuação judiciária, buscando acompanhar tal evolução humana.

O Tribunal Penal Internacional é o passo atual pós-medidas criadas para a apreciaçáo do fato concreto, como foram os tribunais ad hoc, nos casos em que há crimes contra a humanidade, genocídio e, enfim, de repercussão mundial. Em sua formulação, buscou-se superar as falhas do passado, sendo mantidas as iniciativas nas quais se considerou haver acerto (ou, ao menos, que não se avaliou de tão necessária reformulação). Como já ressaltado, numa análise sumária, um dos pontos de principal relevância é exatamente sua constituição prévia e atuação permanente. No entanto, já aqui importantes questões chamam a atenção: uma, ela não é universal, pois só aqueles países que aderirem ao Estatuto de Roma devem subsumir-se aos seus ditames (na condição de Estado-parte). Outra, se ela é permanente (e a condicional 
tem razão de ser), sua competência é toda voltada para o futuro. Em óptica diversa, sua constituição é fruto de uma convenção, não de uma decisão do Conselho de Segurança. Também sua condição de permanente exige exame mais aprofundado, ainda que sem uma resposta definitiva, porquanto, sem a aceitação de tantos países de inegável importância no cenário intemacional, corre-se o risco de o mesmo tornarse sem efetividade.

Entre suas principais características que o distinguiram em relação aos modelos pretéritos, importante destacar os fundamentais princípios norteadores de sua formaçăo, como segue:

1) o princípio segundo o qual a Corte seria acionada apenas se a jurisdição nacional fosse deficiente para a persecução de crimes graves (princípio da complementaridade, art.17);

2) o princípio segundo o qual a competência da Corte é limitada a quatro crimes particularmente sérios que envolvem a comunidade internacional como um todo: genocídio, crimes contra a humanidade, crimes de guerra e agressão.

Consoante reza o art. $3^{\circ}$ do Estatuto de Roma, a sede será na Haia, Países Baixos ("O Estado Anfitrião").

O preâmbulo, em seu primeiro parágrafo, bem traduz o espírito dos "legisladores", responsáveis por sua confecção, à medida que reconhece não só o interesse dos povos "unidos por laços comuns e de que suas culturas foram construídas sobre uma herança que partilham, e preocupados com o fato deste delicado mosaico vir a quebrar-se a qualquer instante", como põe foco ao que pretende coibir, qual seja, a morte de crianças, homens e mulheres, vítimas de atrocidades inimagináveis e que isto constitui ameaça ã paz, à segurança e ao bem-estar da humanidade.

Há também a previsão de que "os crimes de maior gravidade, que afetam a comunidade internacional no seu conjunto, não devem ficar impunes e que sua repressão deve ser 
efetivamente assegurada, através da adoção de medidas em nivel nacional e do reforço da cooperaçāo intemacional."

Culmina a parte preambular, com o já citado Princípio da Complementaridade, ou seja, estabelece que não será permitido um procedimento diante do TPI quando estiver tramitando um procedimento nacional ou o assunto examinado não seja de natureza tão grave que justifique a intervenção da referida Corte, pois, afinal, é dever de todo Estado exercer sua jurisdição penal contra os responsáveis por crimes internacionais (entre outros preceitos, há expressa menção nos artigos 10, 17, 21 e 80 do Estatuto).

Immanuel Kant, na fase embrionária de sua idéia de federalismo, ${ }^{26}$ pregava a idéia de que, diante da celebração de um tratado, tal como no contrato social originário, estabelecido em uma Nação, os Estados permaneceriam em uma posição de não ingerência em conflitos internos, nos quais se envolvessem outros Estados, também havendo um sistema de forças que protegesse as partes acordantes diante de eventuais ataques das forças estrangeiras.

\begin{tabular}{|c|c|}
\hline & $\begin{array}{l}\text { TRIBUNAL PENAL INTERNACIONAL } \\
\text { TPI }\end{array}$ \\
\hline SEDE & Haia \\
\hline COMPOSICÄO & $\begin{array}{l}18 \text { magistrados (há uma brasileira, Sylvia Steiner, } \\
\text { Des. Federal do TRF/ } 3^{a} \text { Regiäo) }\end{array}$ \\
\hline COMPETÊNCIA & $\begin{array}{l}\text { Júlga os crimes de genocídio; contra a humanidade; } \\
\text { crimes de guerra e crimes de agressão. }\end{array}$ \\
\hline ABRANGẾNCIA & $\begin{array}{l}\text { Somente tem jurisdiçấo sobre os crimes cometidos } \\
\text { depois da instituigão do Estatuto de Roma para os } \\
\text { Estados que ratificaram o Estatuto. } \\
\text { Competente para julgar as pessoas fisicas. } \\
\text { Imprescritibilidade dos delitos. }\end{array}$ \\
\hline EFETTOS DAS DECISÕES & Não há, até agora, nenhum processo findo. \\
\hline
\end{tabular}

\footnotetext{
26ANTOS, Leonel Ribeiro. Republicanismo e Cosmopolitismo. A Contribuiçăo de Kant para a Formação da Idéla Modema de Federalismo. Apud "O Federalismo Europeu. Histónia, Política e Utopia. Instituto de História Contemporânea. Faculdade de Letras da Universidade de Lisboa. Lisboa: Colibri, 2001, p. 35.
}

Cadernos do PPG em Direito UFRGS, Porto Alegre, v. 6, n. 7 e 8, p. 489-512, 2007. 


\section{Conclusão}

Nesta inesgotável capacidade humana de conceber e efetivar atos lesivos, a lei sempre perderá para o potencial criativo do homem de perpetrar condutas ainda não previstas em lei. E, quando nấo é o caso de lacunas do direito material em si, é na parte processual que podem se esconder aqueles que desafiam a lei.

Entendemos que a humanidade obteve relevantes avanços na criaçăo e na elaboração de novos sistemas jurídicos à altura das novidades trazidas pelo mundo contemporâneo.

Não há dúvidas de que houve diligência e presteza no processo de criação de Órgãos (judiciais ou não) e sistemas normativos com o escopo de pôr fim à costumeira escusa de que falhas graves ocorriam por "falta de previsão legal". Esta não é mais a justificativa cabível nos casos de crimes extremos contra a humanidade, desobediência e violação a princípios de direitos humanos ou em questões cujos interesses concerniam a Estados soberanos dịstintos.

Os Órgãos trazidos neste estudo traduzem propostas concretas e realizáveis no afã de construirmos uma sociedade que conjugue o progresso material e o crescimento com a paz mundial. A problemática ainda existente é relativa ao cumprimento dessas medidas e à efetiva execução das decisões.

Entretanto, quando recordamos que os primeiros passos pertinentes à proteção dos direitos humanos (e, em seu bojo, a criação de órgãos de atuação supranacional) tiveram início há apenas sessenta anos, parece razoável concluir que há condiçōes de se confiar no estabelecimento de um posicionamento firme e categórico, também quanto à execução das decisôes proferidas pelos Órgãos estudados, de forma a fortalecer o sistema de normas garantidoras do direito, da paz e do exercício contínuo e livre de uma cidadania universal, acima das influências e dos interesses políticos, particulares e sectários. 


\section{Referências}

BAZELAIRE, Jean-Paul; CRETIN, Thierry A justiça penal internacional. São Paulo: Manole, 2003.

CAIERO, Pedro. Tribunais Penais Internacionais: etapas de um caminho ou astros em constelaçáo, doutrina internacional. Revista Brasileira de Ciências Criminais, Sāo Paulo, n. 37,2002

CANEDO, Carlos. O genocidio como crime internacional Belo Horizonte: Del Rey, 1999

CASSESSE, Antonio; MEIRELLE, Delmas-Marty. Crimes internacionais e juris diçóes internacionais. Sä Paulo: Manole, 2004.

FREIBURG I. Br. Albin Eser e JORG Arnold, Direito Penal Intemacional para a Proteção dos Direitos Humanos. In: SIMPOSIO DA FACULDADE DE DIREITO DA UNIVERSIDADE DE COIMBRA E GOETHE-INSTITUT DE LISBOA, Fim de Século, 2003.

HUNGRLA, Nelson. Comentários ao Código Penal. 4. ed. Rio de Janeiro: Forense, 1958 . v. 1, t. 1 .

JAPIASSÚ, Carlos Eduardo Adriano. O Tribunal Penal Internacional: a internacionalizaçăo do direito penal. Rio de Janeiro: Lúmen Juris, 2004.

MAlA, Marrielle. Tribunal Penal Intemacional: aspectos institucionais, jurisdiçäo e princípio da complementaridade. Belo Horizonte: Del Rey, 2001.

PIOVESAN, Flávia. O sistéma interamericano de proteçăo dos direitos humanos $e$ o direito brasileiro. Săo Paulo: Revista dos Tribunais, 2000.

PIOVESAN, Flávia. Obra disponivel em <http//wwwdhnetorgbr/direitos/ militantes/flaviapiovesan/piovesan ruanda html> Acesso em: 03 mar 2005 .

SANTOS, Juarez Cirno dos. Direto penal a nova parte geral Rio de Janeiro: Forense, 1985 .

SILVA, Pablo Rodrigo Alfien da. Tribunal Penal Internacional: aspectos fundamentais e o novo Código Penal Internacional alemäo. Porto Alegre: Fabris, 2004 